\title{
Spesifitas Biologis Air Susu Ibu
}

\author{
Rulina Suradi
}

\begin{abstract}
Air susu mamalia adalah species specific (komposisi masing-masing susu mamalia sangat berbeda). Sebagaimana susu sapi adalah makanan terbaik untuk anak sapi maka ASI adalah makanan terbaik untuk bayi manusia, juga untuk bayi yang lahir kurang bulan. Penambahan atau pengurangan zat di dalam susu sapi agar dapat ditolerir oleh bayi manusia berupa susu formula memerlukan penelitian yang canggih yang perlu mempertimbangkan bukan hanya zat gizinya tetapi seyogianya segala komponen yang ada di dalam ASI. Perubahan komposisi ASI yang disesuaikan dengan masa kehamilan, usia bayi dan cara bayi menyusu tidak dapat ditiru oleh susu formula apalagi keuntungan lain seperti, mencegah penyakit bayi dan ibu serta keuntungan psikologis dan ekonomi.
\end{abstract}

Kata kunci: air susu ibu, biospesifitas.

elama dalam kandungan bayi mendapat segala kebutuhannya melalui plasenta. Setelah bayi lahir kebutuhan ini diberikan oleh kelenjar mama. Kelenjar mama seringkali disebut plasenta ekstrauterin oleh karena melanjutkan fungsi plasenta sebagai pemberi nutrisi dan lainnya kebutuhan bayi setelah bayi lahir. Cairan yang dihasilkan kelenjar mama yaitu Air Susu Ibu (ASI) sering disebut "darah putih" karena komposisinya mirip darah plasenta. Sebagaimana darah, ASI dapat mentransport nutrien, meningkatkan imunitas, merusak patogen dan berpengaruh pada sistem biokimiawi tubuh manusia. Sebagai contoh pada bayi yang mendapat ASI eksklusif organ thymus pada usia 4 bulan dua kali lebih besar dibandingkan pada bayi 4 bulan yang hanya mendapat susu formula. ${ }^{1}$

Memang ASI adalah makanan terbaik yang dapat diberikan ibu pada bayinya baik yang cukup bulan maupun yang kurang bulan. Komposisi ASI dapat berubah sesuai dengan kebutuhan nutrisi bayi pada setiap saat. Kandungan enzim dalam ASI yang membantu pencernaan, kandungan zat imun yang

\footnotetext{
Alamat korespondensi:

Dr. Rulina Suradi, Sp.A(K).

Staf Subbagian Perinatologi. Bagian Ilmu Kesehatan Anak FKUI-RSCM.

Jl. Salemba no. 6. Jakarta 10430.

Telepon dan Fax.: 021- 3154020.

* Disampaikan pada P.I.T.- I.D.A.I, Palembang 26 Juni 2001
}

dapat mencegah bayi terinfeksi oleh bibit penyakit tertentu, tidak dapat diganti oleh susu formula. Selain itu pemberian ASI mempunyai keuntungan psikologik baik bagi bayi maupun ibu. Bagi ibu terdapat keuntungan lain seperti pengurangan perdarahan postpartum, penundaan masa subur, pengurangan kemungkinan terkena kanker payudara dan ovarium serta kemudahan pemberian. Belum lagi keuntungan bagi ekonomi keluarga dan negara.

Seharusnya setiap orang terutama petugas kesehatan termasuk para dokter perlu menghayati akan keunggulan ASI bagi bayi dan jangan terlalu cepat menganjurkan tambahan susu formula bila ibu mengeluh ASI nya kurang, tanpa berusaha agar ibu berhasil menyusui. Seandainya bayinya setelah diusahakan maksimal, memang memerlukan tambahan susu formula pilihlah susu formula yang telah berusaha memperbaiki produknya dengan melengkapinya dengan zat zat yang tidak ada dalam susu sapi tetapi terdapat dalam ASI, walaupun hal ini adalah sesuatu yang hampir mustahil.

\section{ASI dibandingkan dengan air susu mamalia lain}

ASI sebagaimana air susu mamalia lain adalah speciesspecific. ASI telah mengalami adaptasi sejak eksistensi 
manusia untuk memenuhi kebutuhan nutrien, antiinfeksi untuk bertahan hidup dan mencapai pertumbuhan dan perkembangan optimal. Kebutuhan akan ASI bayi manusia yang untuk mencapai dua kali berat lahirnya memerlukan waktu kurang lebih 180 hari tentu berbeda dengan kebutuhan anak sapi yang memerlukan 47 hari dan anak tikus yang memerlukan 6 hari untuk mencapai berat yang sama. (Tabel 1).

Tabel 1. Komposisi air susu berbagai spesies

\begin{tabular}{lcccc}
\hline Spesies & $\begin{array}{c}2 \times \mathrm{BL} \\
(\text { hari })\end{array}$ & $\begin{array}{c}\text { Lemak } \\
(\%)\end{array}$ & $\begin{array}{c}\text { Protein } \\
(\%)\end{array}$ & $\begin{array}{c}\text { Karbohidrat } \\
(\%)\end{array}$ \\
\hline Manusia & 180 & 3.8 & 0.9 & 7.0 \\
Sapi & 47 & 3.7 & 3.4 & 4.8 \\
Kambing & 19 & 4.5 & 2.9 & 4.1 \\
Tikus & 6 & 15.0 & 12.0 & 3.0 \\
\hline
\end{tabular}

Dimodifikasi dari Hambraeus ${ }^{2}$ : Pediatr. Clin. North Am,24:17,1977

\section{Perubahan komposisi ASI menurut maturasi}

Faktor yang mempengaruhi komposisi ASI antara lain adalah usia gestasi, usia pascanatal, stadium penyusuan (pada permulaan atau akhir menyusui) serta frekuensi bayi menyusu. Pada tabel 2 terlihat perubahan komposisi ASI dari ibu yang melahirkan cukup bulan (ACB) dibandingkan ASI dari ibu yang melahirkan kurang bulan (AKB) selama 1 bulan postnatal

Seperti terlihat di atas komposisi AKB berbeda dengan komposisi ACB karena bayi kurang bulan memerlukan percepatan pertumbuhan agar dapat tumbuh hampir seperti pertumbuhan intra uterin dan pada usia kurang lebih 6 bulan dapat menyamai berat bayi yang lahir cukup bulan. Memang kalau bayi lahir terlalu prematur seringkali setelah beberapa minggu bayi masih membutuhkan AKB sedangkan ibu telah menghasilkan ACB. Untuk itu sekarang ada human milk fortifier yang dapat menambahkan zat yang diperlukan bayi prematur. Terjadi pula perubahan komposisi sesuai dengan usia pascanatal. Perubahan komposisi seperti ini tidak dapat diberikan kalau bayi mendapat susu formula. Karena menyusu itu adalah suatu proses interaktif, bayi dapat membantu menentukan komposisi ASI. Sebagai contoh seekor ibu kangguru pada suatu saat yang sama menyusui dua ekor anaknya. Yang seekor adalah bayi kangguru yang sudah dapat keluar masuk kantong ibunya sendiri dan seekor lagi adalah bayi kangguru yang baru berusia beberapa hari. Ternyata ASI yang keluar dari kedua puting kelenjar mama ibu kangguru itu berbeda, sesuai dengan kebutuhan masing masing bayi kangguru.

\section{Kebutuhan kalori/energi}

World Health Organization (WHO)/Food Agricultural Organization (FAO) 1980 merekomendasikan bahwa pemasukan enerji untuk bayi sampai 6 bulan adalah $115 \mathrm{kcal}, \mathrm{kg} /$ hari. Namun kebutuhan ini berdasarkan bayi yang mendapat susu formula. Butte ${ }^{4}$ melaporkan bahwa bayi yang mendapat ASI eksklusif selama 4 bulan pertama dengan pemberian enerji lebih rendah dari yang direkomendasi WHO dapat tumbuh secara optimal. Pula Stuf dan Nichols ${ }^{5}$ mengemukakan bahwa kebutuhan bayi yang mendapat ASI eksklusif 20\% di bawah yang direkomendasikan WHO. Ternyata bayi yang mendapat ASI eksklusif setelah usia 3 bulan hanya memerlukan energi $70-75 \mathrm{kcal} / \mathrm{kg} / \mathrm{hari}$.

Tabel 2. Komposisi ASI bayi cukup bulan (ACB) dan ASI bayi kurang bulan (AKB) selama bulan pertama laktasi

\begin{tabular}{llllllllll}
\hline Nutrien & \multicolumn{2}{c}{$3-5$ hari } & \multicolumn{2}{c}{$8-11$ hari } & \multicolumn{2}{c}{$15-18$ hari } & \multicolumn{2}{c}{ 26-29 hari } \\
\cline { 2 - 10 } & ACB & AKB & ACB & AKB & ACB & AKB & ACB & AKB \\
\hline Energi (kkal/dl) & 48 & 58 & 59 & 71 & 62 & 71 & 62 & 70 \\
Lemak (g/dl) & 1.85 & 3.00 & 2.9 & 4.14 & 3.06 & 4.33 & 3.05 & 4.09 \\
Protein $(\mathrm{g} / \mathrm{dl})$ & 1.87 & 2.10 & 1.7 & 1.86 & 1.52 & 1.71 & 1.29 & 1.41 \\
Laktosa $(\mathrm{g} / \mathrm{dl})$ & 5.14 & 5.04 & 5.98 & 5.55 & 6.00 & 5.63 & 6.51 & 5.97 \\
\hline
\end{tabular}

Dari CH Anderson ${ }^{3}$ : Pediatr Clin North Am 32:335-52,1985 


\section{Pertumbuhan bayi}

Terdapat perbedaan pertumbuhan antara bayi yang mendapat ASI dan yang mendapat susu formula. Dari berbagai penelitian terlihat bahwa pada usia 3-4 bulan bayi yang mendapat ASI eksklusif sedikit lebih berat dibandingkan bayi yang mendapat susu formula. Namun setelah itu bayi yang mendapat susu formula akan lebih berat. Tetapi ukuran panjang dan lingkaran kepala sama yang berarti bahwa bayi yang mendapat susu formula mendapat makanan berlebih. ${ }^{6}$

\section{Kandungan gizi}

\section{Lemak}

Kalori dari ASI 50\% berasal dari lemak. Lemak ASI adalah komponen yang paling berubah kadarnya. Lemak ASI terutama terdiri atas trigliserida yang mudah diuraikan menjadi asam lemak bebas dan gliserol oleh enzim lipase yang terdapat dalam usus bayi dan dalam ASI. ${ }^{7}$ Bayi yang mendapat ASI dibandingkan dengan bayi yang mendapat susu formula mempunyai kadar asam asetat dari spektrum asam lemak berantai pendek yang lebih tinggi. Asam asetat bersama monogliserida menghambat pertumbuhan virus, bakteri dan fungus. ${ }^{8}$ Perbedaan warna, konsistensi dan bau feses bayi yang mendapat ASI dan susu formula disebabkan oleh karena kadar sabun yang lebih tinggi pada feses bayi yang mendapatkan ASI.'

Asam lemak esensial merupakan komponen dari semua jaringan tubuh dan diperlukan untuk sintesis membran sel. Otak, retina dan susunan saraf banyak mengandung asam lemak tidak jenuh berantai panjang (LCPUFA) antara lain docosahexanoic acid (DHA). ASI mengandung banyak LCPUFA, selain LA, (18:2n-6) dan ALA (18:3n-3) yang esensial, juga terdapat AA(20:4n-6) dan DHA (22:6n-3) yang sebenarnya dapat disintesis dari LA dan ALA. Namun beberapa penelitian membuktikan bahwa bayi yang mendapatkan susu formula walaupun mengandung LA dan ALA dalam komposisi yang sama dalam ASI, kadar DHA dalam jaringan tubuhnya ternyata lebih rendah dari bayi yang mendapatkan ASI karena kemampuan bayi untuk mengubah LA dan ALA menjadi AA dan DHA masih sangat terbatas. ${ }^{10}$ Penambahan DHA pada susu formula memang menaikkan MDI (mental development index) tetapi tidak sebanyak bila ditambahkan juga AA, tetapi malah menurunkan PDI (psichomotor development index) bila hanya ditambahkan DHA dan tambahan DHA dan AA menaikklan PDI tetapi tidak bermakna. ${ }^{11}$ Perlu pula diperhatikan bahwa penambahan yang tidak seimbang akan mengganggu AA dalam jaringan dan meningkatkan sintesis eicosanoid yang meningkatkan reaksi inflamasi, trombosis, aterosklerosis dan supresi reaksi imun. $^{12}$

Dari Tabel 3 kita dapat menyimpulkan bahwa susu formula bayi perlu ditambahkan DHA agar dapat menyamai ASI. Penambahan DHA saja ternyata mengurangi kadar AA dalam plasma karena terjadi kompetisi antara kedua asam lemak, sehingga perlu juga penambahan AA. Namun seberapa banyak tambahan yang diperlukan? Penelitian Gibson ${ }^{13}$ yang

Tabel 3. Perubahan kadar DHA pada bayi yang mendapat ASI dan bayi yang mendapat susu formula pada saat lahir sampai 6 bulan

\begin{tabular}{llllll}
\hline & Lahir a term & \multicolumn{2}{l}{ Usia 6 bulan } & \multicolumn{2}{l}{ Perubahan } \\
\hline Otak & $400 \mathrm{~g}$ & $650 \mathrm{~g}$ & & & \\
$\quad$ DHA (mg/otak) & 720 & 1,625 & $(1.170)$ & +905 & $(+450)$ \\
Hati & $120 \mathrm{~g}$ & $200 \mathrm{~g}$ & & & \\
$\quad$ DHA (mg/hati) & 336 & $360 \quad(200)$ & +24 & $(-136)$ \\
Lemak tubuh & $560 \mathrm{~g}$ & $2000 \mathrm{~g}$ & & & \\
$\quad$ DHA (mg/lemak total) & 1053 & $1200 \quad(0)$ & +147 & $(-1053)$ \\
Jaringan tanpa lemak & $2420 \mathrm{~g}$ & $5000 \mathrm{~g}$ & & & \\
$\quad$ DHA (mg/total) & 1694 & 2500 & $(1500)$ & +806 & $(-194)$ \\
Total berat & $3500 \mathrm{~g}$ & $7850 \mathrm{~g}$ & & & \\
$\quad$ DHA (mg/total berat) & 3803 & 5685 & $(2870)$ & +1.882 & $(-933)$ \\
\hline
\end{tabular}

Dikutip dari Cunnane SC: Lipids vol 35 no $1^{10}$ 
mencoba menambahkan AA dan DHA dalam berbagai komposisi memperlihatkan bahwa tambahan $0.4 \%$ AA dan $0.25 \%$ DHA menghasilkan kadar yang menyerupai ASI. (Tabel 4 dan 5) membuat rekomendasi penambahan DHA pada susu formula perlu ditentukan sebelumnya berapa kadar LCPUFA yang paling sesuai. Mengingat bahwa begitu sulitnya penambahan PUFA pada susu formula maka

Tabel 4. Rata-rata kadar AA dan DHA plasma bayi setelah mendapat susu formula dengan penambahan AA dan DHA dengan perbandingan tertentu selama 6 minggu dibandingkan dengan ASI dinyatakan dalam \% asam lemak

\begin{tabular}{llllll}
\hline & $\begin{array}{l}\text { Tanpa } \\
\text { tambahan }\end{array}$ & $\begin{array}{l}0.2 \% \mathrm{AA}+ \\
0.2 \% \mathrm{DHA}\end{array}$ & $0.32 \% \mathrm{AA}+$ & $0.4 \% \mathrm{DA}+$ & ASI \\
& 8.1 & 9.5 & 10.3 & $0.25 \%$ DHA & \\
\hline 20:4n-6 (AA) & 37.1 & 36.1 & 36.1 & 36.1 & 11.8 \\
Total n-6 & & & & & 35.4 \\
& 2.4 & 4.0 & 4.0 & 4.2 & 4.4 \\
22:6n-3 (DHA) & 2.4 & 4.7 & 4.6 & 4.8 & 5.6 \\
\hline
\end{tabular}

Tabel 5. Rekomendasi tambahan AA dan DHA oleh pakar

\begin{tabular}{llll}
\hline $\begin{array}{l}\text { Prosentase dari } \\
\text { asam lemak }\end{array}$ & AA & DHA & Rasio \\
\hline FAO/WHO 1994 & & & \\
${\text { ISSFAL 14 } 1995^{15}}^{\text {Child Health Foundation }}$ & 0.50 & 0.35 & 1.43 \\
US FDA GRAS 2001 $^{16}$ & 0.35 & 0.35 & 1.43 \\
\hline
\end{tabular}

Rekomendasi yang terakhir dari US FDA adalah penambahan AA dan DHA dengan perbandingan tambahan AA 1-2 kali tambahan DHA dan masingmasing tidak boleh lebih dari $0.50 \%$ dari seluruh asam lemak. Memang standar baku adalah kadar di dalam ASI. Tetapi kadar di dalam ASI tergantung dari diit ibu. Jadi kadar mana yang akan diambil sebagai standar baku? Ternyata rasio AA dan DHA dalam ASI ibu-ibu dari Asia berbeda dengan ibu-ibu dari Eropa/Amerika Utara dan dengan ibu-ibu dari Amerika Latin (Tabel 6)

Kadar LCPUFA ASI sangat bervariasi, tergantung pada diit ibu dan masa menyusuinya, sehingga dalam

Tabel 6. Rasio AA dan DHA dalam ASI berbagai ibu

\begin{tabular}{llll}
\hline ASI (\% asam lemak) & AA & DHA & Rasio \\
\hline Asia $^{17}$ & 0.46 & 0.37 & 1.64 \\
Eropa dan Amerika Utara $^{18}$ & 0.48 & 0.27 & 2.04 \\
Amerika Latin $^{19}$ & 0.51 & 0.34 & 1.52 \\
\hline
\end{tabular}

barangkali yang perlu dipertimbangkan adalah penambahan zat zat ini ke dalam diet ibu hamil dan menyusui yang telah terbukti meningkatkan kadar DHA dan AA pada neonatus ${ }^{20}$ dan dalam ASI. ${ }^{21}$

\section{Protein}

Sebagian susu formula yang sering disebut humanized telah mengubah perbandingan Casein dan protein Whey mendekati ASI. Demikian pula Taurin, yang tidak terdapat dalam susu sapi cukup banyak terdapat dalam ASI sudah ada yang ditambahkan ke susu formula. Taurin penting karena berfungsi sebagai neurotransmitter dan berperan pada pematangan otak karena berperan dalam absorbsi lemak. (Tabel 7)

\section{Nukleotida}

Nukleotida adalah zat berbasis nitrogen dengan berat

Tabel 7. Komposisi protein antara ASI dan Susu sapi

\begin{tabular}{lll}
\hline & ASI & Susu sapi \\
\hline Protein g/l & 8.9 & 31.4 \\
Casein & 2.5 & 27.3 \\
Whey protein & 6.4 & 5.8 \\
Alfa-lactalbumin & 2.6 & 1.1 \\
Beta-lactoglobin & - & 3.6 \\
Lactoferrin & 1.7 & Sangat sedikit \\
IgA & 1 & 0.03 \\
\hline
\end{tabular}


molekul yang rendah. Nukleotida penting untuk metabolisme energi, reaksi enzimatik, pertumbuhan dan pematangan traktus digestivus. Nukleotida berperan juga pada sistim imun dengan meningkatkan proliferasi limfosit dan meningkatkan aktivitas killer cells. Penelitian Leach ${ }^{22}$ mengemukakan pentingnya nukleotide ditambahkan pada susu formula. Saat ini sudah ada susu formula bayi yang ditambahkan nukleotida.

\section{Karbohidrat}

Karbohidrat utama dalam ASI adalah laktosa. Laktosa hanya terdapat dalam air susu dan tidak terdapat dalam jaringan tubuh lain. Laktosa berada dalam konsentrasi yang paling tinggi di dalam ASI bila dibandingkan dengan air susu mamalia lain dan sering dihubungkan dengan berat otak yang relatif lebih besar bila dibandingkan dengan otak mamalia lain. Laktosa meningkatkan absorbsi Kalsium dan mudah terurai menjadi glukosa yang menjadi sumber energi untuk pertumbuhan otak dan galaktosa yang diperlukan untuk produksi galaktolipids (antara lain cerebroside) yang esensial untuk perkembangan otak. Selain itu dalam ASI terdapat juga oligosakarida yang merangsang pertumbuhan Laktobasilus bifidus yang meningkatkan keasaman traktus digestivus dan menghambat pertumbuhan kuman patogen.

\section{Mineral}

Jumlah kandungan mineral dalam air susu adalah juga species specific dan dihubungkan dengan kecepatan pertumbuhan spesies. (Tabel 8)

Tabel 8. Kadar mineral dalam ASI dan susu sapi (per $100 \mathrm{ml}$ )

\begin{tabular}{llll}
\hline Mineral & Kolostrum & ASI & Susu sapi \\
\hline Natrium (mg) & 48.0 & 15.0 & 58.0 \\
Kalium (mg) & 74.0 & 57.0 & 145.0 \\
Magnesium (mg) & 4.0 & 4.0 & 12.0 \\
Kalsium (mg) & 39.0 & 35.0 & 130.0 \\
Fosfor (mg) & 14.0 & 15.0 & 120.0 \\
Chlor (mg) & 85.0 & 40.0 & 108.0 \\
Ferrum (mcg) & 70.0 & 100.0 & 70.0 \\
Cuprum (mcg) & 40.0 & 40.0 & 14.0 \\
Total & & 200.0 & 700.0 \\
\hline
\end{tabular}

Modifikasi dari Food and Nutrition Board, National Academy of Sciences: Recommended dietary allowances
Bayi yang mendapat ASI menerima cukup Natrium untuk kebutuhan pertumbuhan dan pengganti kehilangan melalui kulit dan urin. Kadar Natrium dalam susu sapi adalah 3,6 kali dari kadar dalam ASI sehingga bayi yang tidak mendapat ASI bila terjadi dehidrasi mudah mengalami kejang karena hipernatremia. Kadar Kalsium dalam ASI lebih rendah dari susu sapi tetapi penyerapan Kalsium dari ASI adalah 67\% dibandingkan dengan $25 \%$ dari susu sapi. Hipokalsemia neonatal dan tetani lebih sering dilihat pada bayi yang mendapat susu formula karena kadar fosfor dalam susu sapi lebih tinggi (rasio Kalsium:Fosfor dalam ASI adalah 2:1 sedangkan dalam susu sapi 1.2:1.0) yang mengakibatkan absorbsi Kalsium berkurang dan ekskresinya bertambah. Walaupun kadar besi dalam ASI rendah jarang bayi yang mendapat ASI mengalami kekurangan zat besi dan dapat mempertahankan kadar ferrumnya sesuai dengan susu formula yang mendapat tambahan besi. Fe dalam ASI diserap 50\% (dibantu oleh laktosa dan vit C dalam ASI) sedangkan Fe dalam susu formula hanya diserap 10\%. Belum lagi kehilangan darah melalui traktus digestivus yang diakibatkan oleh kerusakan mukosa pada bayi yang mendapat susu formula. Selain itu ASI mengandung trace elements yang memegang peran penting pada pertumbuhan dan perkembangan bayi.

\section{pH, Osmolaritas dan Renal Solute Load}

pH ASI adalah lebih tinggi dari $\mathrm{pH}$ susu sapi, tepi berat jenisnya hampir sama 1.031 berbanding 1.032 . Osmolaritas ASI hampir menyamai serum yaitu 286 mosmol. Osmolaritas susu sapi adalah 350 mosmol. Renal solute load adalah beban berupa zat yang perlu dikeluarkan oleh ginjal karena berada lebih di dalam tubuh. Renal solute load untuk ASI jauh lebih kecil dari renal solute load susu formula.

Tabel 9. PH, Osmolaritas dan Renal solute load ASI dan Susu sapi

\begin{tabular}{lll}
\hline & ASI & Susu sapi \\
\hline PH & 7.1 & 6.8 \\
Osmolaritas (mosmol/kg air) & 286 & 350 \\
Renal solute load (mosmol) & 79 & 221 \\
\hline
\end{tabular}




\section{Faktor anti infeksi}

Dalam kandungan fetus mendapatkan antibodi yang berasal dari ibunya melalui plasenta. Namun setelah lahir, neonatus belum mempunyai cukup kemampuan untuk menghadapi dunia di luar uterus yang terkontaminasi dengan kuman lain, oleh karena antara lain daya fagositosis yang belum sempurna. SIgA yang
6 bulan dan kemudian bagaimana memberikan ASI bersama makanan pendamping ASI yang sesuai dan adekuat. Namun apabila masih ada kendala yang mengakibatkan bayi tidak dapat diberikan ASI secara eksklusif dan memerlukan tambahan susu formula, maka pilihlah susu formula yang telah berusaha memperbaiki produknya sesuai dengan penelitian terakhir.

Tabel 10. Faktor protektif di dalam ASI

\begin{tabular}{ll}
\hline Faktor antibakteri & Efektif terhadap antara lain \\
\hline SIgA & E. Coli, C. Tetani, C Diphteriae. K. Pneumoniae, \\
& Salmonella, Shigella, Streptokokus, H. influenzae \\
& Virus: Pilio, Rubella, CMV, Rotavirus, Influensa, RSV \\
& Parasit: G. lamblia, E.histolitika \\
& V. Cholerae, E. coli \\
IgG, IgM & Virus: Rubella, CMV, RSV \\
& E. Coli \\
IgD & Enterobacteriacea, patogen enterik \\
Bifidobacterium bifidum & E. Coli \\
Laktoferin & Streptokokus, Pseudomonas, E. coli, S. typhimurium \\
Laktoperoksidase & E. coli, Salmonella \\
Lysozyme & Dengan cara fogositosis, pembentukan interferon, \\
Makrofag,neutrofil,limfosit & sitokin dan limfokin \\
Lipid & S. aureus \\
& H. simplex \\
& G. lamblia, E. histolytica T. vaginalis \\
\hline
\end{tabular}

terdapat dalam ASI memberikan proteksi lokal pada mukosa traktus digestivus. Selain itu di dalam ASI terdapat zat penangkal penyakit yang berupa faktor selular dan faktor humeral. Di bawah ini terdapat tabel yang menunjukkan beberapa zat di dalam ASI yang mempunyai efek protektif terhadap bayi.

\section{Kesimpulan}

Setelah menyadari akan keunggulan ASI dan bahwa saat ini masih sangat mustahil untuk dapat mengubah susu sapi menjadi susu formula yang dapat menggantikan posisi ASI sebagai makanan tunggal bagi bayi sampai berusia 6 bulan, Insya Allah sebagai petugas kesehatan kita semua mendukung program ASI eksklusif sampai 6 bulan. Untuk itu kita perlu mengetahui bagaimana caranya membantu ibu agar dapat menyusui bayinya secara eksklusif sampai dengan

\section{Daftar Pustaka}

1. Hasselbach H, dkk,. Decreased thymus size in formulafed infants compared with breastfed infants. Acta Paedtr 1996; 85:1029-32.

2. Hambraus. Pediatr Clin North Am 1977; 24:17.

3. Anderson CH. Human milk feeding. Ped Clin North Am 1985; 32:335-52.

4. Butte NF, Smitheo, Garza C. Energy utilization of breastfed and formula-fed infants. Am J Clin Nutr 1990; 51:350-8

5. Stuff JE, Nichols GL. Nutrient intake and growth performance of older infants fed human milk. J Paeditr 115:959-68.

6. Yoneyama K, Nagata H, Asano H. Growth of Japanese breast-fed and bottle-fed infants from birth to 20 months. Annu Hum Biol 1994; 21:597-608.

7. Hammosh M. Human Milk. Dalam: Colon AR, MohsenZ, penyunting. Pediatric Physiology. Boston: Little, Brown, 1985:69-85.

8. Siigur U, Ormission A, Tamm A. Faecal short-chain fatty acids in breastfed and bottle-fed infants. Acta Paediatr 1993; 82:536-8. 
9. Quinlan PT, dkk,. The relationship between stool hardness and stool composition in breast- and formula-fed infants. J Pediatr Gastroenterol Nutr 1995; 20:81-90.

10. Cunnane SC, Francescutti V, Brenna JT, Crawford MA. Breastfed infants achieve a higher rate of brain and whole body docosahexaenoate accumulation the formula-fed infants not consuming dietary docohexaenoate. Lipids 2000; 35:105-11.

11. Birch EE, Garfield S, Hoffman DR, Uauy R, Birch DG'. A randomized controlled trial of early diatery supply of long-chain polyunsatutated fatty acids and mental development in term infants.

12. Kinsella JE, Broughton KS, Whelan JW. Dietary unsaturated fatty acids: interactions and possible needs in relation to eicosanoid synthesis. J Nutr Biochem 1990; 1:123-41.

13. Gibson RA, Makrides M, Hawkes JS, Neumann MA, Euler AR. A randomized trial of arachidonic acid dose in formulas containing docohexanoic acid in term infants.
The Fourth International Congress on Essential Fatty Acids and Eicosanoids. Edinburgh, Scotlanf, July 1997.

14. FAO/WHO Report of a joint Expert Consultation, Chapter 7, Lipids in early development, Food and $\mathrm{Nu}-$ trition Paper no 57, Fats and Oils in Human Nutrition, Rome: FAO 1994.h.49-55.

15. Simopoulus A dkk,. Essentiality of and recommended diatary intakes for omega- 6 and omega- 3 fatty acids. Ann Nutr Metab 1999; 43:127-30.

16. Koletzko B, Agostoni C, Carlson SE, dkk,. Long chain polyunsaturated fatty acids (LCPUFA) and perinatal development, Acta Paediatrica 2000; 90:460-64.

17. Al MD, van Houwelengin AC, Hornstra G. Long-chain polyunsaturated fatty acids, pregnancy and pregnancy outcome. Am J Clin Nutr 2000 01,71: 1 Suppl, 285S91S.

18. Leach JL, dkk,. Total potentially available nucleotides of human milk by stage of lactation. Am J Clin Nutr 1995; 61:1224-30. 